\title{
Sialometry and sialochemistry: diagnostic tools for Sjögren's syndrome
}

W W I Kalk, A Vissink, F K L Spijkervet, H Bootsma, C G M Kallenberg, A V Nieuw Amerongen

\begin{abstract}
Background-The common occurrence of xerostomia in Sjögren's syndrome (SS) as well as the easy accessibility of saliva supports the use of sialometry and sialochemistry in the diagnosis of SS. Collection and analysis of whole saliva (oral fluid) is currently the routine technique for sialometry, despite the fact that it is rather inaccurate and impure.
\end{abstract}

Objective-To assess the value of glandular sialometry and sialochemistry as diagnostic instruments in SS.

Methods-In a group of 100 consecutive patients referred for diagnosis of SS, glandular secretory flow rates and a spectrum of salivary components (sodium, potassium, chloride, calcium, phosphate, urea, amylase, total protein) were assessed. The patients were classified as positive or negative for SS according to the revised European classification criteria.

Results-Patients with SS differed clearly from those who tested negative for SS, showing lower submandibular/sublingual (SM/SL) flow rates and an appreciably changed salivary composition of parotid and SM/SL saliva. Besides changes in salivary flow rate and composition, distinct sialometric profiles were observed, characteristic of either early or late salivary manifestation of SS, or of the xerogenic side effects of medication.

Conclusions-Glandular sialometry and sialochemistry are not only useful tools for differentiating SS from other salivary gland disease in clinical practice, but they also have great potential as diagnostic criteria for SS, showing distinct sialometric and sialochemical changes as well as profiles. Being simple, safe (non-invasive), and sensitive (early disease detection), they have three major advantages over other oral tests for SS.

(Ann Rheum Dis 2001;60:1110-1116)

Sjögren's syndrome (SS) is considered to be an autoimmune exocrinopathy resulting in, among many other manifestations, tear and salivary gland dysfunction. As the aetiopathogenesis of SS remains unclear, its diagnosis is still based on the presence of characteristic signs and symptoms. A variety of diagnostic tests is currently in use, but none of them detects changes pathognomonic for SS. Therefore, different combinations of test criteria have been proposed for the diagnosis of SS..$^{1-7}$ As lachrymal and salivary gland dysfunction are key manifestations of SS, it seems logical to use the dysfunction of these glands for its diagnosis. ${ }^{8-12}$ Most combinations of test criteria, however, emphasise histopathological, serological, and radiological features rather than gland function itself.

Dysfunction of salivary glands is assessed by measuring salivary flow rate (sialometry) and by chemical analysis of saliva (sialochemistry). Sialochemistry has been proposed as a tool for the differential diagnosis of various salivary gland diseases, including $\mathrm{SS},{ }^{13-16}$ as many salivary gland diseases are well documented in the literature with regard to their sialochemical manifestations. ${ }^{17-19}$

Sialometry can be used as a diagnostic tool mainly in two ways: collection of whole saliva-that is, combined secretions of all salivary glands - and collection of glandular saliva - that is, gland specific saliva. ${ }^{20}$ In the assessment of the secretory capacity of a patient, at first glance measurement of the total secretions accumulating in the mouth (oral fluid) seems to be the most appropriate method, reflecting the overall capacity of all salivary glands. Collection of whole saliva is the method most often used because it is very easy to perform, taking only a few minutes, without the need for a collecting device. For analytical purposes, however, whole saliva is of limited value, as it detects neither dysfunction of any of the separate salivary glands nor gland specific sialochemical changes. ${ }^{9}{ }^{1621}$ Another argument against its use is that does it not necessarily represent the sum of individual gland secretions but may include contamination with sputum, serum, food debris, and many other nonsalivary components. Nevertheless, only a reduced rate of secretion of unstimulated whole saliva is currently considered to be of diagnostic value in SS. ${ }^{4622}$ In contrast, the collection of glandular saliva may reveal preferential involvement of salivary glands, such as selective hyposecretion of the submandibular/ sublingual (SM/SL) salivary glands, which has often been observed in SS. ${ }^{23-26}$ In addition, sialochemistry of the collected glandular saliva samples may show several characteristic changes in electrolytes and proteins (enzymes) in SS, reflecting the effect of autoimmune attack on the secretory cells in individual salivary glands. ${ }^{27}$

Previous studies examined the value of glandular sialometry and sialochemistry in subjects with SS compared with healthy subjects. ${ }^{13} 2526$ In clinical practice, however, SS needs to be differentiated from other salivary gland diseases and conditions mimicking SS. ${ }^{28}$ In the 
present study, the potential value of glandular sialometry and sialochemistry as diagnostic tools for SS was explored by comparative examination of glandular secretory flow rates and a spectrum of salivary components, assessed in a non-selected group of patients referred for evaluation of SS who were subsequently diagnosed as positive or negative for SS.

\section{Patients and methods PATIENTS}

One hundred consecutive patients referred to the outpatient clinic of the Department of Oral and Maxillofacial Surgery of the University Hospital Groningen in the period from September 1997 until March 1999 participated in this study. Patients suspected of having SS were referred by rheumatologists, internists, neurologists, ophthalmologists, ENT specialists, general practitioners, and dentists. Reasons for referral included dry mouth, dry eyes, swelling of the salivary glands, arthralgia, and fatigue. The diagnostic work up for SS was carried out in all patients and included the following aspects: subjective complaints of oral and ocular dryness, ${ }^{6}$ sialography, histopathology of salivary gland tissue, serology (SSA and SSB antibodies), and eye tests (Rose Bengal staining and Schirmer tear test). In addition to these diagnostic tests, the duration of oral symptoms was assessed, defined as the time from first complaints induced by or related to oral dryness until referral. Short duration was defined as less than one year, and long duration as more than two years of oral symptoms. Sialometry, as proposed in the European criteria, was not used as a criterion in the diagnostic work up, in order to avoid any incorporation bias when investigating sialometry as a diagnostic tool for SS. Instead, parotid sialography was used to fulfil the criteria on the oral component.

In this study, the revised European classification criteria for $\mathrm{SS}^{62-31}$ were used as reference standard for the diagnosis of SS, categorising patients as primary SS (group A), secondary SS (group B), or negative for SS (group C).

The use of xerogenic drugs - that is, antihypertensives, $\beta$ blockers, antihistaminics, and psychotropics - was relatively common in all patients (group A, $30 \%$; group $\mathrm{B}, 60 \%$; group C, 55\%).

SALIVA COLLECTION AND CHEMICAL ANALYSIS All salivary assessments were performed in the absence of acute sialadenitis. If clinical signs of acute inflammation were present, the assessment was postponed until they had subsided for at least six weeks.

Glandular saliva was collected in a standardised manner. In brief, patients were instructed not to eat, drink, or smoke for 90 minutes before the sialometric assessment. All assessments were performed at a fixed time of the day, in this study between 1 and $3 \mathrm{pm}$, in order to minimise fluctuations related to a circadian rhythm of salivary secretion and composition. All assessments were performed by the same observer. Glandular saliva was collected in preweighed plastic tubes from each parotid gland by using modified Lashley cups (CarlsonCrittenden cups), and simultaneously from the SM/SL glands by syringe aspiration..$^{32}$ Saliva from the SM/SL glands was collectively aspirated; separate aspiration is difficult in clinical practice because of the close anatomical relation between the orifices of the two glands and the common presence of communicating ducts between the submandibular and sublingual main ducts.

Unstimulated salivary secretions were collected over five minutes, followed by stimulated secretions over 10 minutes. Stimulation was with citric acid solution $(2 \% \mathrm{w} / \mathrm{v})$ applied with a cottonwool swab to the lateral borders of the tongue at 30 second intervals. Mixing of the acid solution applied to the tongue and SM/SL saliva pooling anteriorly in the floor of the mouth (orifices of the SM/SL glands) was carefully avoided. The lag phase, defined as the time from first acid application to the tongue until first visible saliva secretion (in the tubes connected to the cups), was recorded for both parotid glands.

After the saliva samples had been weighed to calculate flow rates (assuming the specific gravity of saliva is $1.0 \mathrm{~g} / \mathrm{cm}^{3}$ ), sialochemical analysis was performed. The following salivary components were quantified: sodium, potassium, chloride, calcium, phosphate, urea, total protein, and amylase. Sodium and potassium ions were measured by flame photometry with lithium ions as a standard (3000 ppm). Chloride ions were measured by titration with silver ions. Calcium ions were measured spectrophotometrically at 577 and $600 \mathrm{~nm}$ after complexation with $o$-cresolphthalein. ${ }^{34}$ Inorganic phosphate was measured at 340 and $383 \mathrm{~nm}$ after addition of molybdate and reduction with bisulphite in the presence of $p$-methylaminephenolsulphate. ${ }^{35} 36$ Urea was measured at $340 \mathrm{~nm}$ after addition of urease/ glutamate dehydrogenase. ${ }^{37}$ Total protein was measured at $604 \mathrm{~nm}$ after addition of pyrogallol. Amylase was quantified by the method of Pierre et al. ${ }^{38}$

\section{SIALOMETRIC ANALYSIS}

To compare the secretory capacities of the major salivary glands, and unstimulated with stimulated flow rates, secretory flow rates were defined. Unstimulated flow rates from the parotid gland and SM/SL glands of $\leqslant 0.03$ $\mathrm{ml} / \mathrm{min} /$ gland were considered low. Stimulated flow rates were considered to be reduced when they were below the mean minus $\mathrm{SD}$ of the controls (group D). Accordingly, stimulated parotid flow rates were considered low when between 0.10 and $0.05 \mathrm{ml} / \mathrm{min} / \mathrm{gland}$, and as extremely low when $\leqslant 0.05 \mathrm{ml} / \mathrm{min} /$ gland. Likewise, stimulated SM/SL flow rates were considered low when between 0.20 and 0.05 $\mathrm{ml} / \mathrm{min} /$ glands, and as extremely low when $\leqslant 0.05 \mathrm{ml} / \mathrm{min} /$ glands. 
Table 1 Characteristics of patients tested for Sjögren's syndrome (SS)

\begin{tabular}{|c|c|c|c|}
\hline & $\begin{array}{l}\text { Group } A \\
(n=33)\end{array}$ & $\begin{array}{l}\text { Group } B \\
(n=25)\end{array}$ & $\begin{array}{l}\text { Group } C \\
(n=42)\end{array}$ \\
\hline Mean age at time of referral (years) & 51 & 54 & 55 \\
\hline Sex (male/female) & $3 / 30$ & $4 / 21$ & $2 / 40$ \\
\hline Xerogenic medication & $10(30 \%)$ & $15(60 \%)$ & $23(55 \%)$ \\
\hline Chronic fatigue & $21(63 \%)$ & $19(76 \%)$ & $29(69 \%)$ \\
\hline Salivary gland swelling ${ }^{\star}$ & $17(51 \%)$ & $7(28 \%)$ & $8(19 \%)$ \\
\hline \multirow[t]{8}{*}{ Connective tissue disease } & $0(0 \%)$ & RA: $14(56 \%)$ & RA: $7(17 \%)$ \\
\hline & & SLE: $4(16 \%)$ & SLE: $2(5 \%)$ \\
\hline & & Scleroderma: $1(4 \%)$ & Scleroderma: $1(2 \%)$ \\
\hline & & CREST: $1(4 \%)$ & \\
\hline & & Vasculitis: $1(4 \%)$ & \\
\hline & & PBC: $1(4 \%)$ & \\
\hline & & Polymyositis: 1 (4\%) & \\
\hline & & Overlap syndrome: $2(8 \%)$ & \\
\hline Positive salivary gland biopsy & $32(97 \%)$ & $24(96 \%)$ & $0(0 \%)$ \\
\hline \multicolumn{4}{|l|}{ Positive serology } \\
\hline SSA & $28(85 \%)$ & $13(52 \%)$ & $3(7 \%)$ \\
\hline SSB & $15(45 \%)$ & $8(32 \%)$ & $1(2 \%)$ \\
\hline Positive eye test $†$ & $25(76 \%)$ & $17(68 \%)$ & $18(43 \%)$ \\
\hline \multicolumn{4}{|l|}{ Parotid sialography $\ddagger$} \\
\hline Sialectasia (positive for SS) & $28(100 \%)$ & $16(76 \%)$ & $3(8 \%)$ \\
\hline \multicolumn{4}{|l|}{ Subjective complaints $\llbracket$} \\
\hline Dry eyes & $24(73 \%)$ & $20(80 \%)$ & $28(67 \%)$ \\
\hline Dry mouth & $32(96 \%)$ & $23(92 \%)$ & $31(74 \%)$ \\
\hline
\end{tabular}

Group A, patients with primary SS; group B, patients with secondary SS; group C, patients who tested negative for SS.

*Present at first visit.

†According to European criteria (at least one positive eye test). ${ }^{6}$

$\ddagger$ According to Blatt, ${ }^{50}$ percentages based on the number of patients with available information.

\According to definition by European classification criteria. ${ }^{6}$

RA, Rheumatoid arthritis; SLE, systemic lupus erythematosus; CREST, calcinosis, Raynaud's phenomenon, oesophageal dysmotility, sclerodactyly, telangiectasis; PBC, primary biliary cirrhosis.

STATISTICAL ANALYSIS

Data were submitted for statistical analysis using the Statistical Package for the Social Sciences (SPSS), version 8.0. The following statistical procedures were applied: test for association according to Spearman, $\chi^{2}$ statistic, Mann-Whitney U test, and analysis of variance (multiple comparison according to Scheffé). In the Results section, the statistical test applied for each situation is stated. A significance level of 0.05 was predefined in all cases.

\section{Results}

STUDY GROUP

By applying the revised European classification criteria for SS to the studied cohort, patients were categorised as primary SS (group A), secondary SS (group B), or negative for SS (group C). The latter were diagnosed on the basis of additional clinical and laboratory tests as having sialoadenosis $(n=10)$, sodium retention dysfunction syndrome $(\mathrm{n}=12)$, medication induced xerostomia $(n=9)$, or no alternative disease directly related to salivary gland pathology $(n=11)$.
Group A, patients with primary SS, comprised three men and 30 women (male/female ratio 1:10; mean (SD) age 51 (16) years (range 21-84)). Group B, patients with secondary SS, comprised four men and 21 women (male/ female ratio 1:5; mean (SD) age 54 (12) years (range 25-78)). Connective tissue diseases of patients with secondary SS comprised rheumatoid arthritis $(n=14)$, systemic lupus erythematosus $(n=4)$, scleroderma $(n=1)$, CREST (calcinosis, Raynaud's phenomenon, oesophageal dysmotility, sclerodactyly, telangiectasis) $(n=1)$, vasculitis $(n=1)$, primary biliary cirrhosis $(n=1)$, polymyositis $(n=1)$, and overlap syndromes $(n=2)$. Group C, patients tested negative for SS, comprised two men and 40 women (male/female ratio 1:20; mean (SD) age 55 (17) years (range 20-81)) (table 1). A fourth group, group D, comprised 36 non-medicated healthy subjects without a history of salivary gland diseases (16 men/20 women; mean (SD) age 39 (12) years (range 23-58)). This group served as historical controls for sialometry and sialochemistry, assessed with the same methods as used in this study. ${ }^{26}$

Table 2 Salivary flow rate of SS positive patients (groups A and B: primary and secondary Sjögren's syndrome respectively), $S S$ negative patients (group C), and healthy controls (group D)

\begin{tabular}{|c|c|c|c|c|}
\hline & $\begin{array}{l}\text { Group } A \\
(n=33)\end{array}$ & $\begin{array}{l}\text { Group B } \\
(n=25)\end{array}$ & $\begin{array}{l}\text { Group } C \\
(n=42)\end{array}$ & $\begin{array}{l}\text { Group D } \\
(n=36)\end{array}$ \\
\hline \multicolumn{5}{|l|}{ Unstimulated } \\
\hline Parotid flow rate $(\mathrm{ml} / \mathrm{min} /$ gland $)$ & $0.02(0.04) \dagger$ & $0.02(0.04) \dagger$ & $0.04(0.06)$ & $0.05(0.06)$ \\
\hline $\mathrm{SM} / \mathrm{SL}$ flow rate $(\mathrm{ml} / \mathrm{min} /$ gland $)$ & $0.05(0.09)^{\star}+$ & $0.02(0.03)^{\star} \dagger$ & $0.12(0.13)$ & $0.12(0.12)$ \\
\hline Lag phase (seconds) & $212(212)^{\star} \dagger$ & $119(180) \dagger$ & $52(83) \dagger$ & $9(54)$ \\
\hline \multicolumn{5}{|l|}{ Stimulated } \\
\hline Parotid flow rate $(\mathrm{ml} / \mathrm{min} /$ gland $)$ & $0.12(0.13) \dagger$ & $0.24(0.25) \dagger$ & $0.19(0.15) \dagger$ & $0.52(0.42)$ \\
\hline $\mathrm{SM} / \mathrm{SL}$ flow rate $(\mathrm{m} / \mathrm{min} /$ gland $)$ & $0.24(0.28)^{\star} \dagger$ & $0.26(0.35) \dagger$ & $0.42(0.28)$ & $0.46(0.24)$ \\
\hline
\end{tabular}

Values are mean $(\mathrm{SD})$.

* Significant difference between SS positive and SS negative patients.

+Significant difference between patients and healthy controls. Statistical test used: analysis of variance.

SM/SL, Submandibular/sublingual. 
Table 3 Composition of stimulated glandular saliva from SS positive patients (groups A and B: primary and secondary Sjögren's syndrome respectively), SS negative patients (group C), and healthy controls (group D)

\begin{tabular}{|c|c|c|c|c|c|c|c|c|}
\hline & \multicolumn{4}{|c|}{ Parotid glands (mean of two sides) } & \multicolumn{4}{|c|}{ Submandibular/sublingual glands } \\
\hline & $\begin{array}{l}\text { Group } A \\
(n=33)\end{array}$ & $\begin{array}{l}\text { Group } B \\
(n=25)\end{array}$ & $\begin{array}{l}\text { Group } C \\
(n=42)\end{array}$ & $\begin{array}{l}\text { Group D } \\
(n=36)\end{array}$ & $\begin{array}{l}\text { Group } A \\
(n=33)\end{array}$ & $\begin{array}{l}\text { Group } B \\
(n=25)\end{array}$ & $\begin{array}{l}\text { Group } C \\
(n=42)\end{array}$ & $\begin{array}{l}\text { Group D } \\
(n=36)\end{array}$ \\
\hline Sodium $(\mathrm{mmol} / \mathrm{l})$ & $26(23)^{\star} \dagger$ & $23(22)^{\star}$ & $4(4) \dagger$ & $14(12)$ & $20(15)^{\star} \dagger$ & $16(11)^{\star} \dagger$ & $6(6) \dagger$ & $11(6)$ \\
\hline Potassium $(\mathrm{mmol} / \mathrm{l})$ & $23(6)$ & $23(9)$ & $30(21) \dagger$ & $24(6)$ & $21(21)$ & $18(7)$ & $20(6) \dagger$ & $17(6)$ \\
\hline Chloride $(\mathrm{mmol} / \mathrm{l})$ & $30(14)+$ & $37(28)^{\star}+$ & $18(6)$ & $16(12)$ & $27(15)+$ & $34(35)^{\star}+$ & $16(5)$ & $16(6)$ \\
\hline Calcium $(\mathrm{mmol} / \mathrm{l})$ & $1.3(1.0)$ & $1.0(0.2)$ & $1.3(0.8)$ & $0.8(0.6)$ & $1.9(0.9)$ & $1.9(0.5)$ & $2.2(1.6)$ & $1.7(0.6)$ \\
\hline Phosphate $(\mathrm{mmol} / \mathrm{l})$ & $4.5(2.4)$ & $4.2(1.6)$ & $5.8(2.9)$ & ND & $2.3(1.2)^{\star}$ & $2.5(1.2)^{\star}$ & $3.9(1.7)$ & ND \\
\hline Urea $(\mathrm{mmol} / \mathrm{l})$ & $5.6(2.0)$ & $4.9(2.4)$ & $6.1(2.5)$ & $3.8(1.2)$ & $2.9(1.8)$ & $3.8(2.3)$ & $4.0(1.9)$ & $2.5(0.6)$ \\
\hline Total protein $(\mathrm{g} / \mathrm{l})$ & $1.2(0.5) \dagger$ & $1.6(1.3) \dagger$ & $1.2(0.6) \dagger$ & $0.6(0.6)$ & $0.6(0.3)$ & $0.8(0.5)$ & $0.7(0.4)$ & $0.8(0.6)$ \\
\hline Total protein $(\mathrm{g} / \mathrm{min})$ & $0.1(0.1)$ & $0.3(0.5)$ & $0.2(0.2)$ & $0.3(0.3)$ & $0.2(0.2)$ & $0.3(0.6)$ & $0.3(0.3)$ & $0.4(0.3)$ \\
\hline Amylase $\left(10^{3} \mathrm{U} / 1\right)$ & $519(344)$ & $618(474)$ & $842(486) \dagger$ & $590(510)$ & $117(97)$ & $162(293)$ & $138(121)$ & ND \\
\hline Amylase $\left(10^{3} \mathrm{U} / \mathrm{min}\right)$ & $59(65)$ & $180(295)$ & $152(142)$ & $307(264)$ & $45(60)$ & $27(60)$ & $58(70)$ & ND \\
\hline
\end{tabular}

Data are expressed as mean (SD) and are based on the number of patients with available information.

* Significant difference between SS positive and SS negative patients.

†Significant difference between patients and healthy controls. Statistical test used: analysis of variance (multi comparison according to Scheffé)

ND, Not determined.

SIALOMETRY

The lag phase was significantly increased in groups $\mathrm{A}, \mathrm{B}$, and $\mathrm{C}$ compared with group $\mathrm{D}$ (table 2) and was inversely related to flow rate $\left(r_{\text {parotid }}-0.51, \mathrm{p}<0.01\right)$.

Mean stimulated parotid flow rate in groups $\mathrm{A}, \mathrm{B}$, and $\mathrm{C}$ was reduced compared with normal (group D) (table 2). Patients in group B had significantly higher stimulated parotid flow rate than patients in group A (table 2). Unstimulated and stimulated SM/SL flow rates were lower in patients in groups A and B than in patients in groups $\mathrm{C}$ and $\mathrm{D}$ (table 2).

\section{SIALOCHEMISTRY}

Sialochemical results listed in table 3 are limited to stimulated saliva samples, as the volume of unstimulated samples was insufficient for full sialochemical assessment in most of the patients studied (A, 75\%; B, 76\%; C, 36\%; D, $0 \%$ ). In $8 \%$ of the patients in this study, sialochemistry was not performed because of absence of measurable salivary secretion (A, $18 \%$; B, $8 \%$; C, $0 \% ; D, 0 \%)$. No significant differences in calcium and urea concentrations were observed between the four groups.

In groups $\mathrm{A}$ and $\mathrm{B}$, mean sodium and chloride concentrations in parotid saliva were sixfold and twofold respectively higher than in group $C$. In groups $A$ and $B$, the mean phosphate concentration in SM/SL saliva was two thirds of the concentration in group $\mathrm{C}$. The total amount of amylase being secreted (U/ min) was appreciably less in groups A, B, and C than in group $\mathrm{D}$. Total protein concentration in

Table 4 Presence of characteristic sialometrical profiles in SS positive patients (groups A and B: primary and secondary Sjögren's syndrome, respectively) and SS negative patients (group $C$ )

\begin{tabular}{|c|c|c|c|}
\hline & $A(n=33)$ & $B(n=25)$ & $C(n=42)$ \\
\hline \multicolumn{4}{|l|}{ SS related profiles } \\
\hline $\begin{array}{l}\text { 1. Normal SM/SL and parotid flow rates with } \\
\text { changed composition }\end{array}$ & $6(18)$ & $5(20)$ & 0 \\
\hline $\begin{array}{l}\text { 2. Low stimulated SM/SL flow rate with } \\
\text { normal parotid flow rate }\end{array}$ & $5(15)$ & $6(24)$ & $1(2)$ \\
\hline 3. Extremely low stimulated SM/SL flow rate & $3(9)$ & $4(16)$ & 0 \\
\hline $\begin{array}{l}\text { 4. Extremely low stimulated SM/SL and } \\
\text { parotid flow rates }\end{array}$ & $10(30)$ & $4(16)$ & $1(2)$ \\
\hline \multicolumn{4}{|l|}{ Miscellaneous } \\
\hline $\begin{array}{l}\text { 5. Low unstimulated with normal stimulated } \\
\text { SM/SL and parotid flow rates }\end{array}$ & $4(12)$ & $2(8)$ & $9(21)$ \\
\hline
\end{tabular}

Values are number of patients (percentage) within the group for whom the profile applies. SM/SL, Submandibular/sublingual. parotid saliva was higher in patients in groups $\mathrm{A}, \mathrm{B}$, and $\mathrm{C}$ than in those in group $\mathrm{D}$, but did not differ significantly between groups A, B, and $C$. In groups $A$ and $B$, the sialochemical electrolyte changes in SM/SL saliva paralleled the changes in parotid saliva.

Salivary composition did not differ significantly between the patients of groups A and B.

In group $\mathrm{C}$, significant changes in salivary composition were observed compared with healthy controls (group D). Increases in potassium and amylase concentration and a decrease in sodium concentration in parotid and SM/SL saliva were observed.

The sialochemical differences observed when groups $\mathrm{A}$ and $\mathrm{B}$ were compared with group C were also observed when groups A and B were compared with group D. However, the former were more clear cut because of the decreased mean salivary sodium concentration in group $\mathrm{C}$ contrasting with the sodium increase in groups A and B. A relatively large spread was present (large SD) in most sialochemical variables because the concentration of many salivary constituents is related to salivary flow rates. ${ }^{18} 19$

EARLY SALIVARY MANIFESTATION IN SS

In about a fifth of the patients in groups $\mathrm{A}$ and B (18\% and $20 \%$ respectively), sialometry showed normal flow rates, accompanied by considerably changed salivary composition, including increased sodium and chloride concentrations. This combination of normal flow rates and changed salivary composition was not observed in groups $\mathrm{C}$ and $\mathrm{D}$ (table 4 ). About a fifth of the patients in groups A and B $(15 \%$ and $24 \%$ respectively) showed low stimulated flow rate from the SM/SL glands accompanied by a (sub)normal flow rate from the parotid glands. This selective hyposecretion was observed in one of the patients in group $\mathrm{C}$ and in none of the patients in group D (table 4). These profiles are characteristic of early salivary manifestation of SS, as both occurred almost exclusively in the SS groups (A and B) and are related to short duration (less than one year) of oral symptoms (tables 4 and 5).

LATE SALIVARY MANIFESTATION IN SS

Extremely low stimulated flow rate for exclusively the SM/SL glands was found in about a 
Table 5 Relation between presence of characteristic sialometric profiles and duration of oral symptoms in patients who tested positive for Sjögren's syndrome (groups $A$ and $B ; n=58$ )

\begin{tabular}{|c|c|c|c|c|}
\hline & \multicolumn{2}{|l|}{ Months } & \multicolumn{2}{|c|}{ Significance } \\
\hline & Present & Absent & Uvalue & $p$ Value \\
\hline \multicolumn{5}{|l|}{ Sialometric profiles } \\
\hline \multicolumn{5}{|l|}{ Early salivary manifestations } \\
\hline $\begin{array}{l}\text { 1. Normal SM/SL and parotid flow rates with } \\
\text { changed composition }\end{array}$ & 5 & 32 & 74 & $<0.01$ \\
\hline $\begin{array}{l}\text { 2. Low stimulated SM/SL flow rate with normal } \\
\text { parotid flow rate }\end{array}$ & 11 & 30 & 138 & 0.09 \\
\hline \multicolumn{5}{|l|}{ Late salivary manifestations } \\
\hline 3. Extremely low stimulated SM/SL flow rate & 63 & 12 & 43 & $<0.01$ \\
\hline $\begin{array}{l}\text { 4. Extremely low stimulated SM/SL and parotid } \\
\text { flow rates }\end{array}$ & 74 & 16 & 35 & $<0.01$ \\
\hline
\end{tabular}

Statistical test used: Mann-Whitney U test.

tenth of the Sjögren patients (A, 9\%; B, 16\%) whereas extremely low flow rates for all major salivary glands were found in a quarter ( $A$, $30 \%$;, $16 \%)$. Extremely low flow rates for all salivary glands were observed in one of the patients in group $\mathrm{C}$ and in none in group $\mathrm{D}$ (table 4). These profiles proved, retrospectively, characteristic of late salivary manifestation of SS, as both occurred almost exclusively in the SS groups (A and B) and were related significantly to long duration (more than two years) of oral symptoms (tables 4 and 5).

CHANGES UNRELATED TO SS

A combination of low unstimulated flow rates and (sub)normal stimulated flow rates for all salivary glands was found in a tenth of the patients in groups $\mathrm{A}$ and $\mathrm{B}(12 \%$ and $8 \%$ respectively), in a fifth of the patients in group C $(21 \%)$, and was not observed in group D (table 4). The presence of this combination of low unstimulated and normal stimulated flow rates related significantly to the use of psychotropic drugs $\left(\chi^{2} 5.0, \mathrm{p}<0.05\right)$. The low unstimulated flow rates originate from a suppressive drug effect on the SM/SL glands, which are physiologically the most active glands in the unstimulated condition. Unstimulated SM/SL flow rate related significantly in the groups studied to the use of psychotropic drugs $\left(r_{\mathrm{s}}-0.29, \mathrm{p}<0.01\right)$ and the use of any xerogenic drug $\left(r_{\mathrm{s}}-0.27, \mathrm{p}<0.01\right)$.

SECRETORY FLOW RATE AS FUNCTION OF TIME Mean duration of oral symptoms before patients attended our outpatient clinic for salivary assessment was 32 months for group A (median 14, range 0-168) and 29 months for group B (median 12, range 0-120). All glandular secretory flow rates were inversely related to duration of oral symptoms in groups $\mathrm{A}$ and $\mathrm{B}\left(r_{\mathrm{s}(\text { stim-parotid })}-0.64 ; r_{\mathrm{s}(\text { stim-SM/SL) }}-0.72 ; r_{\mathrm{s}(\text { lag- }}\right.$ phase) $0.63 ; \mathrm{p}<0.01)$. On average, the reduction of stimulated SM/SL flow rate preceded the reduction in stimulated parotid flow rate, as shown by the common occurrence of selective or relatively strong hyposecretion of the SM/SL glands in groups A and B (table 4).

\section{Discussion}

The results from this sialometric and sialochemical study show a variety of potentially clinically applicable differences between patients with a positive diagnosis of SS and patients tested negative for SS. As the data for patients with primary SS and secondary SS did not differ significantly, the two groups of patients are considered together in the discussion.

Our data confirm that results from previous studies showing reduced SM/SL flow rate in $\mathrm{SS}^{223-26}$ also apply in a clinical setting, when patients with SS are compared with patients with clinical conditions resembling SS (nonSS). A possible explanation for this appreciably reduced flow rate is early involvement of the $\mathrm{SM} / \mathrm{SL}$ glands in SS. Although the underlying mechanism is not yet understood, it seems that measuring SM/SL flow rate may well contribute to an early diagnosis of SS. In contrast, parotid flow rate was decreased in both SS positive and SS negative patients, which is in accordance with the literature. As a consequence, it can be confirmed that measurement of parotid flow as a single test is of no use in diagnosing SS in clinical practice. ${ }^{921} 2539$

Our findings of significant changes in salivary concentration of sodium, chloride, and phosphate in patients with SS compared with non-SS patients are in agreement with those in many other studies comparing patients with SS with healthy controls. ${ }^{13} 18252640-42$ These sialochemical changes can be used to determine whether salivary gland biopsy is indicated, ${ }^{16}$ but may also serve to differentiate SS from other salivary gland disease. As the observed sialochemical changes are not pathognomonic for $\mathrm{SS}$, it is sometimes difficult to differentiate changes caused by SS (chronic inflammation) from those associated with acute inflammation of salivary glands. ${ }^{9}$ However, the two conditions can be differentiated by the presence of a much higher salivary protein concentration in acute inflammation, resulting from protein leakage from the serum. ${ }^{43}$ In the case of acute exacerbation of a chronic inflammation in SS, much of the increase in sodium and chloride and the decrease in phosphate will persist after the acute inflammation has subsided, and, hence, sampling on a longitudinal basis may be required. ${ }^{18}$

In addition to the diagnostic potential of sialochemical changes in SS, the changes observed in the group of SS negative patients are also useful in the differential diagnosis of salivary gland diseases by clearly showing the presence of other common salivary gland diseases. 
The observed increases in potassium and amylase concentration indicated the presence of a subset of patients with sialoadenosis, whereas the decrease in sodium concentration indicated patients with sodium retention dysfunction syndrome, both non-inflammatory salivary gland diseases. Sialoadenosis is a parenchymatous salivary gland disorder caused by secretory and metabolic disturbances of the acinar parenchyma, which presents clinically with xerostomia and the presence of a bilateral chronic or recurrent painless swelling of the salivary glands, particularly the parotid glands. ${ }^{17} 1844-47$ Sodium retention dysfunction syndrome presents clinically with xerostomia and recurrent unilateral painless swelling of a parotid gland for a few hours. It has been suggested to be related to impaired gland perfusion, which may occur because of homoeostatic mechanisms of the blood supply in favour of other organ. ${ }^{48}$

To understand the reasons for the observed sialochemical changes in SS, the process of saliva production needs to be studied closely. Under normal circumstances, primary saliva is secreted into the acinar lumen and subsequently transported to the oral cavity through the salivary ducts by contraction of epimyoepithelial cells and other hydrostatic forces. As primary saliva traverses the striated ducts, salivary composition is modified considerably: phosphate is thought to be slightly concentrated, whereas sodium and chloride are extensively reabsorbed at low flow rate. ${ }^{9} 19$

In SS, however, a common defect in the major salivary glands is suggested by the parallel sialochemical changes observed in SM/SL and parotid saliva. As the resorptive and secretory processes are flow dependent, the observed increases in sodium and chloride concentrations and decrease in phosphate concentration would be even more striking if corrected for the low salivary flow rate in patients with SS. ${ }^{18}{ }^{19}$ In spite of the low flow rate, duct cells seem unable to actively reabsorb sodium and chloride and to concentrate phosphate in SS. ${ }^{13}$ One may hypothesise that duct cells are impaired in their function by the periductal lymphocytic infiltration that is present in the major salivary glands affected by SS. ${ }^{25} 49$ Perhaps, locally produced autoantibodies directed against duct cells cause impairment of electrolyte transport in duct cells. The unaltered levels of potassium and calcium in SS do not necessarily oppose this theory of ductal dysfunction, but may indicate that their mode of transport differs from the normal active ductal transport of sodium, chloride, and phosphate.

The observation of sialometric profiles, characteristic of either early or late salivary manifestation of SS or the side effect of drugs may be useful in diagnosing SS. The early profiles are important for detecting the presence of SS shortly after disease onset when other symptoms may still be inconspicuous. Furthermore, the early and late profiles would seem to be useful for staging the disease with regard to its oral component, comparable with the use of sialography for staging glandular changes in
SS. ${ }^{50}$ The profile characteristic of xerogenic drug use is useful to show the presence of a suppressive drug effect on the secretory function of salivary glands. In the case of drug induced xerostomia, often a normal stimulated salivary flow rate and composition is observed, whereas the unstimulated flow rate is substantially reduced. Because drugs are the most common inducers of oral dryness, it is strictly necessary to explore drug effects as the cause of this symptom as well as other systemic causes.

The applicability of sialometry and sialochemistry as diagnostic instruments varies in different clinical conditions. In the case of relatively normal salivary gland function, as may be present in the initial phase of SS-when autoimmune inflammation has not yet resulted in significant loss of secreting cells-sialometry is of little use as a diagnostic tool. In this situation, however, sialochemistry is often useful, because sialochemicalchanges - reflecting autoimmune attack on secretory cells - usually precede salivary gland dysfunction in SS. In the case of severe salivary gland dysfunction, as may be present in a more advanced phase of SS-when autoimmune inflammation has resulted in massive loss of active secretory cells - it may not be possible to use sialochemistry as a diagnostic instrument because of lack of saliva. In this situation, however, sialometry is highly diagnostic for SS. ${ }^{28}$ Therefore, it is advisable to combine sialometry and sialochemistry as diagnostic instruments, and assess their joint diagnostic value in early as well as advanced phases of SS.

In conclusion, glandular sialometry and sialochemistry are useful for differentiating SS from other salivary gland diseases, showing not only separate changes in salivary flow rate and composition but also characteristic sialometric profiles. Currently, sialometric and sialochemical results, if obtained at all, are taken into account when deciding whether additional (more invasive) diagnostic procedures are required. ${ }^{16}$ To transform sialometry and sialochemistry from a method of differentiating salivary gland diseases into a diagnostic tool applicable to incipient and advanced stages of SS, cut off values for the relevant variables need to be determined and analysed in addition to this survey. ${ }^{28}$ Several sialometric and sialochemical variables have the potential to differentiate SS from non-SS to such an extent that an optimal combination of variables may result in a test with high diagnostic value. Therefore, if applied and interpreted properly, this method may be an excellent tool for diagnosing the oral component of SS, being simple, safe (noninvasive), and sensitive (early disease detection). If proved to be sufficiently accurate, it may subsequently be a valuable supplement to, or even replace, current oral tests in the international test criteria for SS.

Perhaps in the future, other sialochemical variables may be added to the list of markers for SS, such as cytokines, interleukins, hyaluronic acids, and certain proteins, which are currently under investigation. ${ }^{51-54}$ However, some of these markers lack the direct relation to loss and dysfunction of exocrine gland 
tissue, which is the major outcome of SS, but merely reflect complex inflammatory processes or co-processes in the disease. Therefore, these markers may be more useful for understanding the immunopathogenesis of SS rather than in its diagnosis. Furthermore, sialometry probably has the potential to be used to assess progression of SS (at least with regard to the oral component). However, to clarify the prognosis of salivary gland function and other aspects of disease progression, a long term prospective study, as previously suggested, is still required..$^{40}$

The advice and support of Dr B Stegenga (Oral and Maxillofacial Surgeon, Epidemiologist, University Hospital Groningen and $\mathrm{Dr} \mathrm{Kh}$ Mansour (Ophthalmologist, University Hospital Groningen) are gratefully acknowledged.

1 Shearn MA. Sjogren's syndrome. Major Probl Intern Med 1971;2:1-262.

2 Daniels TE, Silverman S, Michalski JP, Greenspan JS, Sylvester RA, Talal N. The oral component of Sjögren's syndrome. Oral Surg Oral Med Oral Pathol 1975;39:87585.

3 Homma M, Tojo T, Akizuki M, Yamagata H. Criteria for Sjögren's syndrome in Japan. Scand J Rheumatol Suppl 1986;61:26-7.

4 Manthorpe R, Oxholm P, Prause JU, Schiødt M. The Copenhagen criteria for Sjögren's syndrome. Scand J Rheumatol 1986;61 Suppl:19-21.

5 Skopouli FN, Drosos AA, Papaioannou T, Moutsopoulos HM. Preliminary diagnostic criteria for Sjögren's synHM. Preliminary diagnostic criteria for Sjögre
drome. Scand J Rheumatol 1986;61 Suppl: $22-5$.

6 Vitali C, Bombardieri S, Moutsopoulos HM, Balestrieri G, Bencivelli W, Bernstein RM, et al. Preliminary criteria for the classification of Sjögren's syndrome. Results of a prospective concerted action supported by the European Community. Arthritis Rheum 1993;36:340-7.

7 Fox RI, Saito I. Criteria for diagnosis of Sjögren's syndrome. Rheum Dis Clin North Am 1994;20:391-407.

8 Fox PC, Van der Ven PF, Sonies BC, Weiffenbach JM, Baum BJ. Xerostomia: evaluation of a symptom with increasing significance. J Am Dent Assoc 1985;110:51925.

9 Thorn JJ, Prause JU, Oxholm P. Sialochemistry in Sjögren's syndrome: a review. J Oral Pathol Med 1989;18:457-68.

10 Schiødt M, Thorn JJ. Criteria for the salivary component of Sjögren's syndrome. A review. Clin Exp Rheumatol 1989;7:119-22.

11 Daniels TE. Clinical assessment and diagnosis of immunologically mediated salivary gland disease in Sjögren's syndrome. J Autoimmun 1989;2:529-41.

12 Pennec YL, Letoux G, Leroy JP, Youinou P. Reappraisal of tests for xerostomia. Clin Exp Rheumatol 1993;11:523-28.

13 Mandel ID, Baurmash H. Sialochemistry in Sjögren's syndrome. Oral Surg Oral Med Oral Pathol 1976;41:18287.

14 Benedek-Spät E. Sialochemical examinations in nontumorous parotid enlargements. Acta Otolaryngolica Stockholm 1978;86:276-82.

15 Ben-Aryeh H, Spielman A, Szargel R, Gutman D, Scharf J, Nahir M, et al. Sialochemistry for diagnosis of Siögren's syndrome in xerostomic patients. Oral Surg Oral Med Oral Pathol 1981;52:487-90.

16 Mandel ID. The diagnostic uses of saliva. J Oral Pathol Med 1990;19:119-25.

17 Rauch S, Gorlin RJ. Diseases of the salivary glands. In: Gorlin RJ, Goldman HM, eds. Thoma's oral pathology. St Louis: CV Mosby, 1970:962-1070.

$18 \mathrm{Mandel}$ ID. Sialochemistry in diseases and clinical situations affecting salivary glands. Crit Rev Clin Lab Sci 1980 tions affecting

19 Michels LF. Sialometry and sialochemistry. In: Graamans $\mathrm{K}$, Akker van den HP, eds. Diagnosis of salivary gland disorders. Dordrecht: Kluwer Academic Publishers, 1991:13962.

20 Veerman EC, Keijbus van den PAM, Vissink A, Nieuw Amerongen AV. Human glandular salivas: their separate collection and analysis. Eur J Oral Sci 1996;104:346-52.

21 Skopouli FN, Siouna FH, Ziciadis C, Moutsopoulos HM Evaluation of unstimulated whole saliva flow rate and stimulated parotid flow as confirmatory tests for xerostomia. Clin Exp Rheumatol 1989;7:127-29.

22 Sreebny LM, Zhu WX. Whole saliva and the diagnosis of Sjögren's syndrome: an evaluation of patients who
complain of dry mouth and dry eyes. Part 1. Screening tests. Gerodontology 1996;13:35-48.

23 Daniels TE, Powell MR, Sylvester RA, Talal N. An evaluation of salivary scintigraphy in Sjögren's syndrome. Arthrition of salivary scintigraphy
tis Rheum 1979;22:809-14.

24 Fox PC, Sarras AK, Bowers MR, Drosos AA, Moutsopoulos HM. Oral and sialochemical findings in patients with autoimmune rheumatic disease. Clin Exp Rheumato 1987;5:123-26.
25 Atkinson JC, Travis WD, Pillemer SR, Bermudez D, Wolff A, Fox PC. Major salivary gland function in primary Sjögren's syndrome and its relationship to clinical features. Rheumatol 1990;17:318-22.

26 Vissink A, Panders AK, Nauta JM, Ligeon EE, Nikkels PG, Kallenberg CGM. Applicability of saliva as a diagnostic fluid in Sjögren's syndrome. Ann N Y Acad Sci 1993;694: 325-29.

27 Reijden van-der WA, Kwaak van der JS, Veerman EC, Nieuw Amerongen AV. Analysis of the concentration and output of whole salivary constituents in patients with Sjögren's syndrome. Eur J Oral Sci 1996;104:335-40.

28 Atkinson JC. The role of salivary measurements in the diagnosis of salivary autoimmune diseases. Ann N Y Acad Sci 1993;694:238-51.

29 Vitali C, Moutsopoulos HM, Bombardieri S. The European Community Study Group on diagnostic criteria for Sjögren's syndrome. Sensitivity and specificity of tests for ocular and oral involvement in Sjögren's syndrome. Ann Rheum Dis 1994;53:637-47.

30 Vitali C, Bombardieri S, Moutsopoulos HM, Coll J, Gerli R, Hatron PY, et al. Assessment of the European classification criteria for Sjögren's syndrome in a series of clinically defined cases: results of a prospective multicentre study. The European Study Group on Diagnostic Criteria for Sjögren's Syndrome. Ann Rheum Dis 1996;55:116-21.

31 Vitali C, Bombardieri S, Moutsopoulos HM, and the European Study Group on Diagnostic Criteria for Sjögren's Syndrome. The European classification criteria for Sjögren's syndrome (SS). Proposal for a modification of the rules for classification suggested by the analysis of the receiver operating characteristic (ROC) curve of the criteria performance [abstract]. J Rheumatol 1997;24:38.

32 Lashley KS. Reflex secretions of the parotid gland. J Exp Psychol 1916;1:461-93.

33 Carlson AJ, Crittenden AL. The relationship of ptyalin concentration to the diet and the rate of secretion of saliva. Am J Physiol 1910;26:169-77.

34 Gitelman HJ. An improved automated procedure for the determination for calcium in biochemical specimens. Anal Biochem 1967;18:521-31.

35 Amador E, Urban J. Simplified serum phosphorus analyses by continuous-flow ultraviolet spectrophotometry. Clin Chem 1972;18:601-4.

36 Daly JA, Ertingshausen G. Direct method for determining inorganic phosphate in serum with the "CentrifiChem". Clin Chem 1972;18:263-5.

37 Talke H, Schubert GE. Enzymatic determination of urea in blood serum by the Warbung optical test. Klin Woch 1965; 43:174-5.

38 Pierre KJ, Tung KK, Nadj H. A new enzymatic kinetic method of determination of amylase [abstract]. Clin Chem 1976;22:1219.

39 Daniels TE, Fox PC. Salivary and oral components of Sjögren's syndrome. Rheum Dis Clin North Am 1992:18: 571-89.

40 Stuchell RN, Mandel ID, Baurmash H. Clinical utilization of sialochemistry in Sjögren's syndrome. J Oral Pathol 1984;13:303-9.

41 Rauch S. Die Speigeldrüsen des Menschen. Stuttgart: Georg Thieme Verlag, 1959:344.

42 Benedek-Spät E, Berényi B, Csiba A. A sialochemical study on patients with Sjögren's syndrome. Arch Oral Biol 1975; 20:649-52.

43 Tabak L, Mandel ID, Herrera M, Baurmash H. Changes in actoferrin and other proteins in a case of chronic recurrent parotitis. J Oral Pathol 1978;7:91-9.

44 Rauch S. Natriumretinierende Sialose. Arch Klin Exp Ohren Nasen Kehlkopfheilkd 1967;188:525-8.

45 Abelson DC, Mandel ID, Karmiol M. Salivary studies in alcoholic cirrhosis. Oral Surg Oral Med Oral Pathol 1976; 41:188-92.

46 Chilla R, Arglebe C. Function of salivary glands and sialochemistry in sialadenosis. Acta Otorhinolaryngol Belg 1983;37:158-64.

47 Mandel L, Hamele Bena D. Alcoholic parotid sialadenosis. J Am Dent Assoc 1997;128:1411-5.

48 Baum BJ. Principles of saliva secretion. Ann N Y Acad Sci 1993;694:17-23.

49 Saito T, Fukuda H, Arisue M, Matsuda A, Shindoh M, Amemiya A, et al. Periductal lymphocytic infiltration of salivary glands in Sjögren's syndrome with relation to clinical and immunologic findings. Oral Surg Oral Med Oral Pathol 1991;71:179-183.

50 Blatt IM. On sialectasis and benign lymphosialoadenopathy. Laryngoscope 1964;74:1684-1746.

51 Grisius MM, Bermudez DK, Fox PC. Salivary and serum interleukin 6 in primary Sjögren's syndrome. J Rheumatol 1997;24:1089-91.

52 Tishler M, Yaron I, Shirazi I, Yaron M. Salivary and serum hyaluronic acid concentrations in patients with Sjögren's syndrome. Ann Rheum Dis 1998;57:506-8.

53 Tishler M, Yaron I, Shirazi I, Yossipov Y, Yaron M. Increased salivary interleukin-6 levels in patients with primary Sjögren's syndrome. Rheumatol Int 1999;18: $125-7$.

54 Beeley JA, Khoo KS. Salivary proteins in rheumatoid arthritis and Sjögren's syndrome: one-dimensional and twodimensional electrophoretic studies. Electrophoresis 1999 20:1652-60. 